\title{
Hydride Generation-in situ Trapping-flame Atomic Absorption Spectrometry Hybridization for Indium and Thallium Determination
}

\author{
Henryk Matusiewicz* and Magdalena Krawczyk
}

\author{
Politechnika Poznańska, Department of Analytical Chemistry, 60-965 Poznań, Poland
}

\begin{abstract}
O desempenho analítico do acoplamento de geração de hidretos com sistema de aprisionamento de átomos (HG-IAT) em espectrometria de absorção atômica com chama (FAAS) foi avaliado para determinação de In e $\mathrm{Tl}$ em material de referência. Hidretos de índio $\left(\mathrm{InH}_{3}\right)$ e tálio $(\mathrm{TlH})$ foram atomizados em sistema IAT aquecido em chama ar-acetileno. Investigou-se um novo arranjo da técnica hifenizada HG-IAT-FAAS, que superaria a capacidade operacional dos arranjos existentes (tubo de sílica resfriado com água, tubo de quartzo com dupla fenda ou "aprisionamento integrado"). Obteve-se significativa melhora nos limites de detecção, em relação às técnicas de aprisionamento de átomos acima citadas. Os limites de detecção, definidos como 3 vezes o desvio padrão do branco

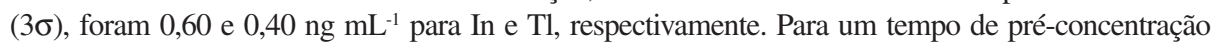
de $120 \mathrm{~s}$ in situ (volume da amostra de $2 \mathrm{~mL}$ ), a melhora na sensibilidade, comparando-se com espectrometria de absorção atômica com chama foi de 417 e 450 para In e Tl, respectivamente, usando a técnica de geração de hidretos e aprisionamento de átomos. A sensibilidade pode ser ainda melhorada aumentando-se o tempo de coleta. A precisão, expressa por RSD, foi de 4,4\% e 5,2\% (n = 6) para In e Tl, respectivamente. Os arranjos estudados incluíram tubo com fenda, tubo simples de sílica e aprisionamento de átomos resfriado e integrado. A precisão e exatidão do método foram verificadas pelo uso do material de referência certificado (GBW 07302 Sedimento) e soluções analíticas de calibração em meio aquoso. Os teores de In e Tl determinados no material de referência apresentaram adequada concordância com os valores certificados ou indicativos.
\end{abstract}

The analytical performance of coupled hydride generation-integrated atom trap (HG-IAT) atomizer flame atomic absorption spectrometry (FAAS) system was evaluated for determination of In and $\mathrm{Tl}$ in reference material. Indium, using formation of $\mathrm{InH}_{3}$ and $\mathrm{TlH}$ vapors were atomized in air-acetylene flame-heated IAT. A new design of HG-IAT-FAAS hyphenated technique that would exceed the operational capabilities of existing arrangements (a water-cooled single silica tube, double-slotted quartz tube or an "integrated trap") was investigated. A dramatic improvement in detection limits was achieved compared with that obtained using either of the atom trapping techniques, presented above, separately. The detection limits, defined as 3 times the blank standard deviation $(3 \sigma)$, were 0.60 and $0.40 \mathrm{ng} \mathrm{mL}^{-1}$ for $\mathrm{In}$ and $\mathrm{Tl}$, respectively. For a $120 \mathrm{~s}$ in situ preconcentration time (sample volume of $2 \mathrm{~mL}$ ), sensitivity enhancement compared to flame AAS, were 417 and 450 folds for In and Tl, respectively, using hydride generation-atom trapping technique. The sensitivity can be further improved by increasing the collection time. The precision, expressed by RSD, was $4.4 \%$ and $5.2 \%(\mathrm{n}=6)$ for In and $\mathrm{Tl}$, respectively. The designs studied included slotted tube, single silica tube and integrated atom trap-cooled atom traps. The accuracy of the method was verified by the use of certified reference material (GBW 07302 Stream Sediment) and by aqueous standard calibration solutions. The measured In and $\mathrm{Tl}$ contents, in reference material, were in satisfactory agreement with the certified or information values.

Keywords: in situ trapping, hydride generation, indium, thallium, flame atomic absorption spectrometry

\section{Introduction}

Indium and thallium are one of the less studied elements in flame, hydride generation and electrothermal

*e-mail: Henryk.Matusiewicz@put.poznan.pl atomic absorption spectrometry (FAAS, HG-AAS, ETAAS).$^{1,2}$ Recent interest in these elements stems partly from the high toxicity of some of its chemical forms. ${ }^{3,4}$ Indium and thallium must therefore be determined in a wide range of matrices, e.g., biological, clinical, geological and/or metallurgical samples. The 
determination of In and $\mathrm{Tl}$ at endogenous level in analytical samples, is a difficult task due to the trace concentrations of the elements. Therefore, in most cases a pre-concentration stage, before the elements can be determined, is essential.

It is well established that significant improvements in the limits for detection of FAAS and ET-AAS may be achieved by chemical vapor generation, mostly hydride generation (HG) and in-atomizer (silica or graphite tube) trapping (pre-concentration) as reviewed ${ }^{5,6}$ for the determination of $\mathrm{As}, \mathrm{Bi}, \mathrm{Ge}, \mathrm{In}, \mathrm{Pb}, \mathrm{Sb}, \mathrm{Se}, \mathrm{Sn}, \mathrm{Te}$ and $\mathrm{Tl}$ (as well as $\mathrm{Hg}$ ).

There are, so far, only four references to indium determination by HG-AAS. In 1982, Busheina and Headridge $^{7}$ first described the generation of indium hydride $\left(\mathrm{InH}_{3}\right)$ with atomization in a silica tube using argon as the carrier gas. In 1984, Yan et al. ${ }^{8}$ modified the reactions conditions and improved the sensitivity for determining indium, and extended the method to thallium by HG-AAS, using an electrically heated quartz tube atomizer. Castillo et al. ${ }^{9}$ made further studies in which the atomizers used were all heated quartz tubes. Liao and $\mathrm{Li}^{10}$ described the application of HG-AAS with in situ pre-concentration in a graphite furnace coated with palladium for the determination of indium.

Reports on the hydride generation of thallium are scarce. ${ }^{8,11-13}$ Yan et al. ${ }^{8}$ developed a batch hydride generation AAS method for the determination of thallium. Ebdon et al. ${ }^{11}$ improved the determination of $\mathrm{Tl}$ with the use of continuous flow hydride generation system for AAS using a flame-heated quartz tube atom cell. Liao et al. ${ }^{12}$ developed a hydride generation and in situ trapping (in the graphite tube) system for the ET-AAS determination of $\mathrm{Tl}$ using tellurium as enhancement reagent. A flow injection hydride generation atomic absorption spectrometric (FI-HGAAS) method, for the determination of trace amount of $\mathrm{Tl}$ using palladium and Rhodamine B as the enhancement reagent (using a quartz tube atomizer) was developed. ${ }^{13}$

Unfortunately, none of these studies reported a successful HG-AAS determination of In and Tl at the ultratrace levels in real samples. In addition, the reported limits of detection are not so low as those currently achievable by the use of in situ atom trapping technique.

In situ trapping technique allows a significant enhancement in sensitivity by comparing batch and continuous generation approaches for the ultra-trace determination of metallic hydrides and vapors. Due to its importance, in situ trapping, which allows the coupling of hydride generation to integrated atom trap (IAT) system, ${ }^{14-16}$ was chosen for this study.
Korkmaz et al. ${ }^{17}$ investigated the nature of revolatilization from atom trap surfaces in flame by AAS. Analytes $\mathrm{Au}, \mathrm{Bi}, \mathrm{Cd}, \mathrm{Mn}$ and $\mathrm{Pb}$ were trapped on a watercooled, U-shaped silica trap or on a slotted silica tube trap and re-volatilized by organic solvent aspiration. These authors concluded that, although heating was not necessarily associated with re-volatilization, direct contact between the flame and the active silica surface was required. Recently, ${ }^{18}$ the analytical performance of the three trap systems (water-cooled U-shaped silica trap, water-cooled U-shaped silica trap combined with slotted silica tube and slotted tube trap) for flame AAS were evaluated for determination of $\mathrm{Cd}$ and $\mathrm{Pb}$ in waters. Guo and $\mathrm{Guo}^{19}$ reported $\mathrm{SeH}_{2}$ collection at gold wire heated to $200{ }^{\circ} \mathrm{C}$ situated in a quartz tube atomizer (AFS or AAS detection) with separate inlet for argon. A successful trapping of $\mathrm{PbH}_{4}$ in a bare quartz tube was announced by Korkmaz et al., ${ }^{20}$ who also suggested that the same trap could also be used for other hydrides. Recently ${ }^{21}$ a preliminary evaluation of quartz tube trap for collection of $\mathrm{SbH}_{3}$ and for volatilization of trapped analyte with subsequent atomization in a multiple microflame quartz tube atomizer for AAS was presented. Very recently, Kratzer and Dedina ${ }^{22}$ extended their investigation of stibine trapping in quartz tube traps ${ }^{21}$ to stibine collection (and subsequent analyte atomization) in conventional quartz tube atomizers. They employed the simplest possible experimental arrangement: just commercially available externally heated quartz tube atomizer without any trap or additional heating device. Further, a modification of the externally heated quartz tube atomizer, making possible in situ trapping of bismuthine and subsequent analyte atomization for $\mathrm{Bi}$ was described. ${ }^{23}$

The aim of this work is to improve analytical performance of indium and thallium conventional hydride generation flow system by combining this approach for in situ trapping technique, integrated atom trap system for flame AAS that is applicable to determination of In and $\mathrm{Tl}$ in certified reference material. This hydride generation-in situ trapping technique brings the FAAS method strikingly better (one order of magnitude) to the detection limits of HG-ET-AAS (in situ trapping technique). ${ }^{10,12}$

\section{Experimental}

\section{Spectrometer}

A Carl Zeiss Jena (Jena, Germany) Model AAS3 flame atomic absorption spectrometer (components described in reference 24) was used with a $10 \mathrm{~cm}$ air-acetylene burner 
assembly and an IBM-PC compatible computer. The sampling rate for the PMT signal was $10 \mathrm{~Hz}$. Signals were processed with in-house software (Turbo Pascal Version 7) to extract the transient peak heights, area and peak time. For In and Tl, hollow cathode lamps (NARVA, Berlin, Germany) were used. No background correction was used throughout. Operating parameters of the AAS instrument are summarized in Table 1 after appropriate optimization.

Table 1. Operating conditions of flame AAS

\begin{tabular}{lll}
\hline & \multicolumn{2}{l}{ Element } \\
\cline { 2 - 3 } Parameter & In & $\mathrm{Tl}$ \\
\hline Wavelenght/nm & 303.9 & 276.8 \\
Resolution/nm & 0.4 & 0.7 \\
Lamp current/mA & 10 & 15 \\
Flame type $^{\mathrm{a}}$ & Air- $\mathrm{C}_{2} \mathrm{H}_{2}$ & Air- $\mathrm{C}_{2} \mathrm{H}_{2}$ \\
Flame conditions $^{\mathrm{b}}$ & Lean & Lean \\
Silica tube obscuration/(\%) & 30 & 30 \\
Coolant water/(L min $\left.{ }^{-1}\right)$ & $c a .2$ & $c a .2$ \\
Window of measurements/s & 15 & 15 \\
Read time/s & 7 & 7 \\
Signal measurement & Peak area absorbance \\
\hline
\end{tabular}

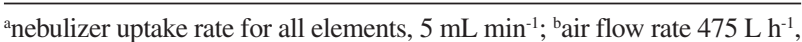
acetylene flow rate $50 \mathrm{~L} \mathrm{~h}^{-1}$ (fuel-lean flame), $10 \mathrm{~cm}$ slot burner.

\section{Hydride generation system}

Hydride generation was accomplished in the continuous-flow mode using a system similar to that described previously. ${ }^{25}$ This system consists of a manually controlled peristaltic pump (Gilson, Minipuls-3), a gas handling network and a reaction cell (volume $40 \mathrm{~mL}$ ).
The PVC/PTFE pump tubing was fitted to the outlet of the continuous system. The internal purge gas supply line to the nebulizer/burner was routed through the inside part of the hydride cell. The outlet of the glass cell and the nebulizer/burner system were connected with a Tygon tubing of dimensions $1.5 \mathrm{~mm}$ i.d. $\times 2.0 \mathrm{~mm}$ o.d. having a length of $30 \mathrm{~cm}$.

Mass flow controller (DHN, Warsaw, Poland) was used to regulate the transfer gas flow rate accurately and precisely.

The operating conditions for continuous flow hydride generation atomic absorption spectrometry are summarized in Table 2. A schematic diagram of the continuous flow HG-IAT-FAAS system with in situ preconcentration in the IAT unit is shown in Figure 1.

\section{Atom trapping techniques}

Three designs of atom trap were investigated. Since the atom trap systems was described in detail in previous papers, ${ }^{6,14,26}$ this will not be discussed again here, but briefly summarized only.

A double-slotted quartz tube (STAT) was installed on a standard $10 \mathrm{~cm}$ air-acetylene burner. The design permits changeover from analysis with the $\mathrm{IAT}^{14}$ to that for a conventional flame in a few seconds.

A water-cooled single silica tube (WCAT) atom trap was arranged, as previously described, ${ }^{26}$ and mounted on a $10 \mathrm{~cm}$ burner in such a manner in order to permit the system to be vertically and laterally adjusted to the flame. The tubes were of an o.d. $3 \mathrm{~mm}$ and an i.d. of $1 \mathrm{~mm}$ for water cooling.

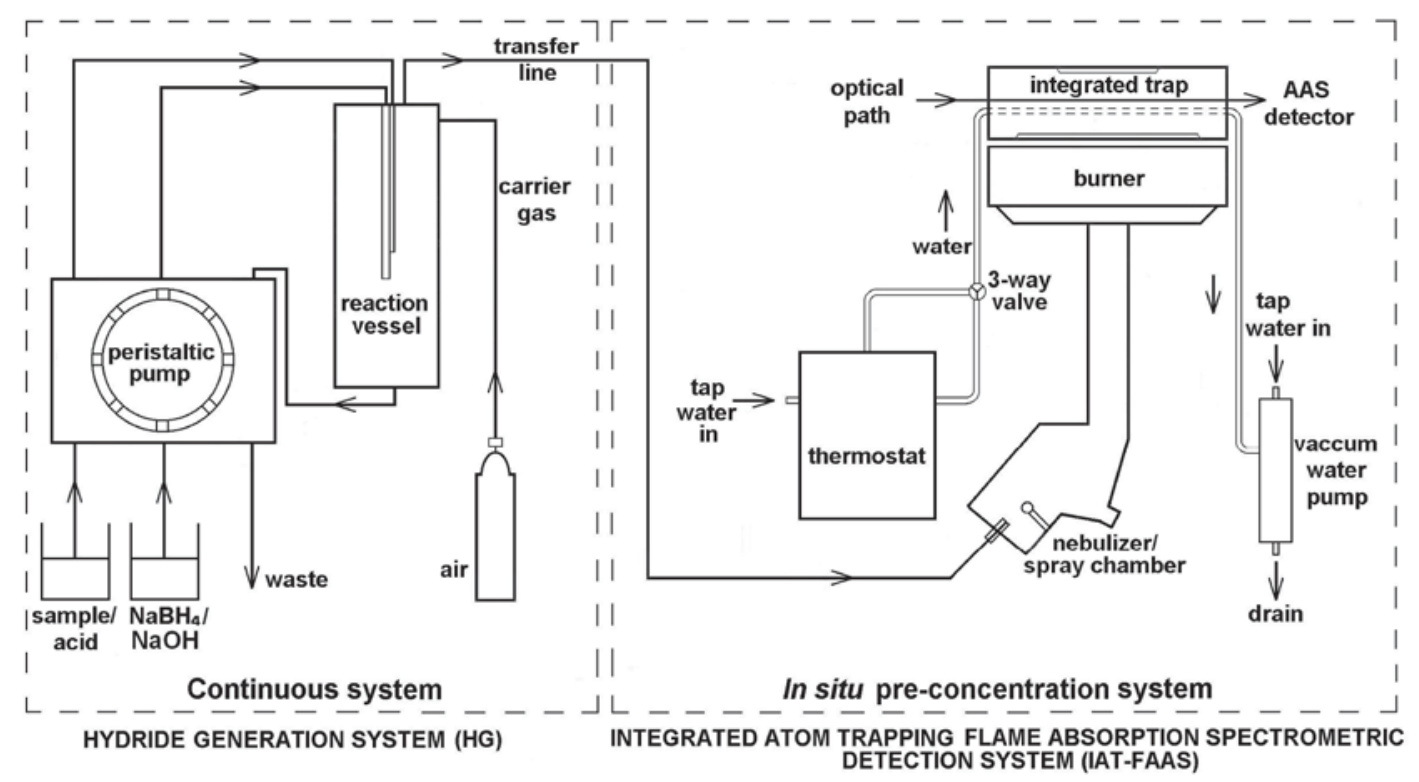

Figure 1. Schematic diagram of the HG-IAT-FAAS system. 
Table 2. Optimized operating conditions for the determination of In and Tl by HG-IAT-FAAS

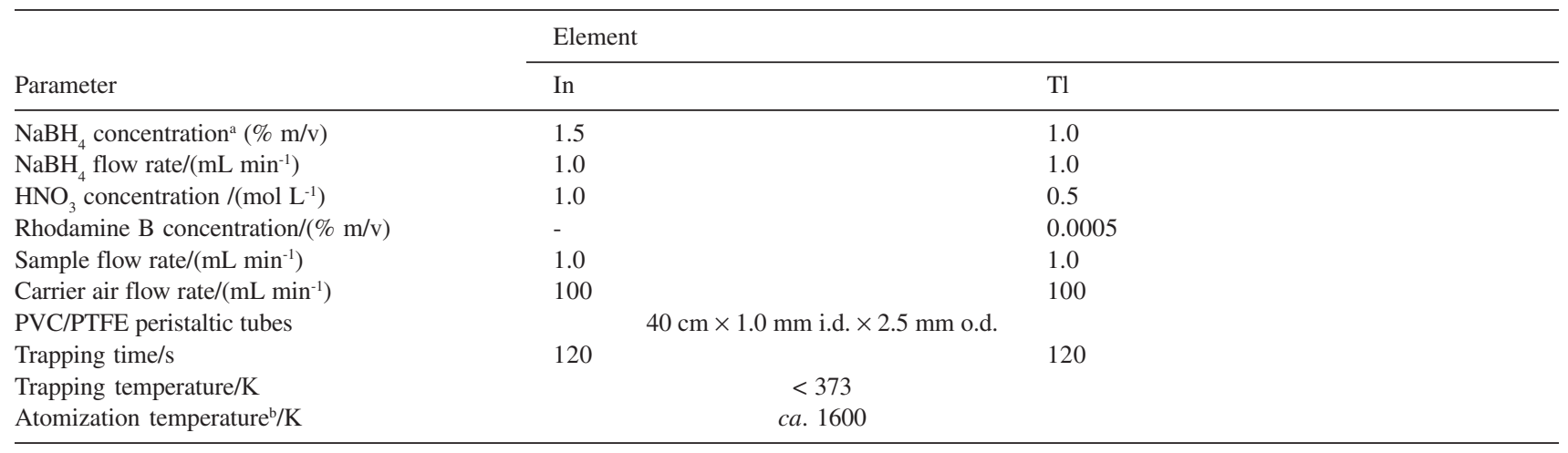

ain $0.5 \%(\mathrm{~m} / \mathrm{v}) \mathrm{NaOH}$ solution; ${ }^{\mathrm{b}}$ reference 26.

An integrated atom trap (IAT) was designed and constructed in this laboratory, ${ }^{14}$ it consisted of a combination of a WCAT and a STAT (see Figure 1 in reference 14). The IAT system was mounted over an airacetylene burner on a mounting bracket, which permitted calibrated movement both vertically and horizontally.

A modified cooling system was used for cooling the water ${ }^{15}$ (see Figure 1 in reference 15). The continuously flowing cooling water kept the surface of the silica tube at the temperature below $100{ }^{\circ} \mathrm{C}$. This allowed the analyte atoms to condense on the surface of the tube.

The single silica and slotted quartz tubes were coated with lanthanum to prevent devitrification and to improve the silica surface properties (increasing the surface area) ${ }^{26}$ by continuous aspiration via the burner nebulizer of $1.5 \%$ $\mathrm{m} / \mathrm{v}$ lanthanum solution for $15 \mathrm{~min}$. The tubes were recoated after approximately 100 runs.

\section{Gases and reagents}

Compressed air gas of N-50 purity (99.999\%) obtained from BOC GAZY (Poznań, Poland) was employed as the carrier gas for the nebulizer/burner unit without further purification. Compressed medical purity acetylene (Cezal, Poznań, Poland) was used as the source of air-acetylene flame.

Reference standard solutions were prepared from a $1000 \mathrm{mg} \mathrm{mL}^{-1} \mathrm{In}(\mathrm{III})$ and $\mathrm{Tl}(\mathrm{I})$ atomic absorption standards (Titrisol grade, Merck, Darmstadt, Germany). Working standard solutions were prepared freshly and daily by diluting appropriate aliquots of the stock solution in highpurity water.

A $1 \%$ or $1.5 \% \mathrm{~m} / \mathrm{v}$ solution of sodium tetrahydroborate (III) was prepared daily, by dissolving proper amounts of $\mathrm{NaBH}_{4}$ (pellets) (Alfa Inorganics, Ward Hill, MA USA) in high-purity water and stabilizing with $0.5 \% \mathrm{~m} / \mathrm{v} \mathrm{NaOH}$ (Suprapur, Merck, Darmstadt, Germany) solution to decrease its rate of decomposition and was used without filtration.

Rhodamine B was prepared by dissolving the powder (POCh, Gliwice, Poland) in water to yield a $0.5 \% \mathrm{~m} / \mathrm{v}$ solution.

The lanthanum chloride solution, used to coat the quartz tubes $(1.5 \% \mathrm{~m} / \mathrm{v})$ was prepared from a $10 \% \mathrm{~m} / \mathrm{v}$ lanthanum chloride solution supplied with Alfa Inorganics (Ward Hill, MA, USA) as a releasing agent for the use in atomic absorption.

Nitric acid $(69 \% \mathrm{~m} / \mathrm{v})$, hydrofluoric acid $(40 \% \mathrm{~m} / \mathrm{v})$ and hydrogen peroxide 30\% (v/v) of the highest quality (Suprapur, Merck, Darmstadt, Germany) were used. Highpurity water: deionized water (model DEMIWA 5 ROSA, Watek, Czech Republic), and doubly distilled water (the second and third distillation was carried out using quartz apparatus, Bi18, Heraeus, Hanau, Germany) were used to prepare all solutions.

\section{Reference material}

Validation of the method described in this work was performed using certified, in total indium and thallium concentrations, solid reference material. The following material: GBW 07302 (Stream Sediment) from National Research Center for CRM's, Beijing, China, was chosen.

\section{Microwave digestion system}

A laboratory-built prototype of high pressuretemperature focused microwave heated digestion system, equipped with a closed TFM-PTFE (Hostaflon TFM is a chemically modified PTFE) vessel $(30 \mathrm{~mL}$ internal 
volume) based on a design outlined in detail by Matusiewicz ${ }^{27}$ was employed for wet-pressure sample digestion.

\section{Recommended analytical procedure}

The whole analytical procedure consists of various steps. It includes: $(i)$ closed wet digestion of the sample, (ii) generation of the $\mathrm{InH}_{3}$ and $\mathrm{TlH}$ vapors and its in situ trapping (collection) in an IAT system, (iii) flame atomization of collected hydrides and (iv) measurement by FAAS.

Microwave-assisted high pressure Teflon bomb digestion

Approximately $250 \mathrm{mg}$ of powdered certified reference material (Stream Sediment) was placed in the TFM-PTFE vessel of the microwave digestion system and moistened by $1 \mathrm{~mL}$ of $30 \% \mathrm{H}_{2} \mathrm{O}_{2}$ and $3 \mathrm{~mL}$ of concentrated $\mathrm{HNO}_{3}$ and $1 \mathrm{~mL}$ of concentrated HF was added. The sample was heated for $10 \mathrm{~min}$ at $150 \mathrm{~W}$. After dissolution, the clear digested solution was transferred into $10 \mathrm{~mL}$ calibrated flask and diluted to volume with water. Before further analysis these were appropriately diluted depending on the concentration level of the elements.

\section{Hydride generation and procedure for in situ trapping}

Hydride generation was accomplished with the use of the continuous system; the application of this generator was described in a previous paper. ${ }^{25}$ In brief, the hydrides were generated in continuous-flow mode and were introduced into the IAT system by the carrier gas (air) during the vapor-trapping step of the atomizer temperature program only; this step lasted for $120 \mathrm{~s}$ in all experiments.

Continuous-flow generation measurements of volatile hydrides (In, Tl) were studied using the system shown schematically in Figure 1. An aliquot containing In and/ or $\mathrm{Tl}$ dissolved in $\mathrm{HNO}_{3} / \mathrm{HF} / \mathrm{H}_{2} \mathrm{O}_{2}$ was placed in a $2 \mathrm{~mL}$ vessel. A $2 \mathrm{~mL}$ volume of sample solution (In) or $2 \mathrm{~mL}$ volume of sample solution and $2 \mu \mathrm{L}$ of $0.5 \% \mathrm{~m} / \mathrm{v}$ rhodamine B (Tl) was analyzed for establishing levels of indium and thallium. The Tygon transfer line from the reaction cell was placed in the nebulizer/burner system. The In and Tl sample was continuously introduced at a flow rate of $1 \mathrm{~mL} \mathrm{~min}^{-1}$ to merge with a $1.5 \%$ or $1 \% \mathrm{~m} / \mathrm{v}$ solution of $\mathrm{NaBH}_{4}$ flowing at $1.0 \mathrm{~mL} \mathrm{~min}^{-1}$. The merging solution feeded the gas-liquid separator to the IAT system. The liquid phase was continuously removed to waste after neutralization with $0.5 \% \mathrm{~m} / \mathrm{v} \mathrm{NaOH}$ solution.

\section{Flame atomization of collected vapors}

After collection stage, vacuum water pump was then turned on to rapidly remove the cooling water from the quartz tube. The tube was rapidly heated in the flame, generating a transient atomic absorption signal as a result of the analyte atoms being released from the surface. Finally, the analytes were atomized for $7 \mathrm{~s}$ at feasible temperature of about $1600 \mathrm{~K}^{26}$

\section{HG-IAT-FAAS analysis}

After completion of the hydride generation and collection stage, the analytes were vaporized by heating the quartz tube up to $1600 \mathrm{~K}$. The integrated absorbance signals peak area were employed at the appropriate lines. A univariate optimization approach was undertaken to establish, for In and $\mathrm{Tl}$, the best conditions for hydrides generation, transport, in situ trapping and vaporization/atomization. Analytical blanks were also carried through the entire procedure outlined above, in order to correct possible contaminants in the reagents that were used for the sample preparation. Quantification of In and $\mathrm{Tl}$ was made from aqueous standard calibration curves (external calibration) verified by the technique of standard additions. All detection limits were calculated for data based on a $3 \sigma$ criterion of the blank counts.

\section{Results and Discussion}

The study included an investigation of the hydride generation with in situ trapping (pre-concentration), the thermal vaporization-atomization into the FAAS, and its application to practical analysis. Therefore, it is convenient to discuss optimization of the parameters affecting the efficiency of hydride generation, collection and analysis technique separately.

\section{Determination of the instrumental and chemical experimental conditions}

The optimized vapor generation conditions are shown in Table 2. The absorption characteristics of major lines for In (303.9 and $325.6 \mathrm{~nm}$ ) and $\mathrm{Tl}(276.8$ and $377.6 \mathrm{~nm}$ ) were investigated using the HG-FAAS method. As a consequence, the In $303.9 \mathrm{~nm}$ and $\mathrm{Tl} 276.8 \mathrm{~nm}$ lines giving the largest signal-to-background ratio were used throughout the process as analytical lines.

The effects of the flame conditions on the trapping and release of the elements were studied by varying the fuel flow rate. The influence of the flame condition on the signal intensity was investigated by fixing the air flow rate $\left(475 \mathrm{~L} \mathrm{~h}^{-1}\right)$ and altering the acetylene flow rate. The result of our experiment showed that the best sensitivity was obtained when using a $50 \mathrm{~L} \mathrm{~h}^{-1}$ flow rate (lean flame) for acetylene and a $475 \mathrm{~L} \mathrm{~h}^{-1}$ flow rate for air during the collection and release cycles. 
The water-cooled silica tube trap position was not optimized in our experiments, but was selected on the basis of previous experience. ${ }^{14}$ The optimum position of the trap tube (single silica tube and STAT) corresponded to the distance (gap) of $5 \mathrm{~mm}$ above the burner, and the position of the silica tube corresponded to obscuration of about onefourth of the light beam by the upper part of the tube. No significant differences were found in the absorbance signals when a coolant water flow rate of $1-4 \mathrm{~L} \mathrm{~min}^{-1}$ was used during the collection cycle of $\mathrm{In}$ and $\mathrm{Tl}$ hydrides.

The trapping (collection) time was one of the most important factors concerning the sensitivity of HG-IATFAAS. In order to ensure, with greater certainty, that all of the hydrides were stripped from the solution and transferred into the atomizer, a reasonable trapping time per sample, in a routine laboratory, should be about $2 \mathrm{~min}$.

Preliminary experiments were performed by HG-AAS with the use of aqueous reference standard solutions of In. It was determined that the generation efficiency of the $\mathrm{InH}_{3}$ species greatly depends on the type of reactor used. It confirms that the batch generation techniques cannot be used efficiently. Therefore, the continuous hydride generation system, throughout the experiments of the trapping and release cycles, was used. Substantial optimization of the generation parameters for In was not undertaken, as this information was already available in the literature pertaining to In detection by atomic absorption. .,2,-10 $^{-10}$

Nitric acid has seldom been used as the acidic medium, as there were almost rare reports on the use of $\mathrm{HNO}_{3}$ as the acidic medium. Instead, most of the research, employed $\mathrm{HCl}$. In both, $\mathrm{HNO}_{3}$ and $\mathrm{HCl}$ systems, acidity of the solution was a very important parameter having great influence on the hydride generation. According to the fact that $\mathrm{HNO}_{3}$ (together with $\mathrm{HF}$ ) is usually used for sediment sample preparation, this acid was also investigated. In this study the use of $\mathrm{HNO}_{3}$ as the acidic medium (main reagent) and its concentration effects on In and $\mathrm{Tl}$ hydride generation was investigated. It was observed that $\mathrm{HNO}_{3}$ imposed similar influence on In and on $\mathrm{Tl}$ hydride generation then in $\mathrm{HCl}$ system.

Several concentrations of $\mathrm{NaBH}_{4}$ and $\mathrm{HNO}_{3}$ were investigated. The concentration of $\mathrm{NaBH}_{4}$ was a parameter of importance for In hydride generation. Concentrations in the range between $0.5-3.0 \%$ of $\mathrm{NaBH}_{4}$ were assayed. It was observed that the higher the concentration of $\mathrm{NaBH}_{4}$ the higher the signal, but relative standard deviations also increased. On the other hand, $\mathrm{NaBH}_{4}$ concentrations higher than $2 \% \mathrm{~m} / \mathrm{v}$ would result in a violent reaction in the gasliquid separator (generator) and eventually lead to an unstable signal. High $\mathrm{NaBH}_{4}$ concentrations had to be avoided and an optimum value of $1.5 \%$, to which a small concentration
$(0.5 \%)$ of $\mathrm{NaOH}$ stabilizer was added in order to maintain the reagent blank as low as possible, was chosen. Nitric acid concentration effect was investigated in the range between 0.5-2.5 mol L-1. It was observed that when acid concentration was lower, lower detection limits were obtained. Therefore, $1.0 \mathrm{~mol} \mathrm{~L}^{-1}$ value was chosen as an optimum.

The continuous hydride generation system was also used for the generation of thallium hydride. First the reagent concentrations of $\mathrm{HNO}_{3}$ and $\mathrm{NaBH}_{4}$ were optimized. The results are shown in Table 2. The $\mathrm{NaBH}_{4}$ had a significant effect on the efficiency of $\mathrm{Tl}$ hydride generation. The signal increased significantly between $0.5-1.0 \% \mathrm{~m} / \mathrm{v} \mathrm{NaBH}_{4}$, and remained stable in the $1-2 \%$ $\mathrm{m} / \mathrm{v}$ range. Eventually a concentration of $1 \%$, to which a small concentration $(0.5 \%)$ of $\mathrm{NaOH}$ was added, was chosen as an optimum. Nitric acid concentration effect was investigated in the range between $0.1-2.0 \mathrm{~mol} \mathrm{~L}^{-1}$; for further experiments $0.5 \mathrm{~mol} \mathrm{~L}^{-1} \mathrm{HNO}_{3}$ was selected. The influence of the presence of the rhodamine and Pd plays a role in the enhancement of generation efficiency of the volatile $\mathrm{Tl}$ hydrides. ${ }^{13}$ For this reason, these reagents were added to the sample solution (to a final concentration of $0.0005 \% \mathrm{v} / \mathrm{v}$ and $1 \mu \mathrm{g} \mathrm{mL} \mathrm{mL}^{-1}$, respectively). It should be pointed out that the presence of Pd hardly had an enhanced effect on Tl hydride generation. Since Pd had no effect on Tl signal enhancement, it was, therefore, not necessary to introduce palladium in following experiments.

The air carrier gas flow through the apparatus is one of the basic parameters having an influence on the transport of the hydrides (volatile species) into the trapflame system, and thus the determination sensitivity. The hydrides were stripped from the hydride generator and were trapped in the silica tube (atomizer) at air flow rates in the range between $25-250 \mathrm{~mL} \mathrm{~min}^{-1}$ with a $120 \mathrm{~s}$ long collection time. It was evident that the use of low carrier gas (air) flow can successfully reduce high analyte losses caused by sorption on the inner surfaces of the apparatus (transport tubing), and therefore such use leads to a slight improvement in the analytical signals. This may be connected with more efficient separation of the hydrides from the reaction solution. On the other hand, higher carrier gas flow rates $\left(>100 \mathrm{~mL} \mathrm{~min}^{-1}\right)$ can result in a decrease in trapping efficiency (higher flow rates reduce peak areas and make peaks markedly broader). An air flow of $100 \mathrm{~mL} \mathrm{~min}{ }^{-1}$ was used in the experiments in order to transport the hydrides completely. In the atomization step, signals with regular shapes were observed for each trapping temperature and were not significantly influenced by the sample introduction time in the tested range between 60 and $180 \mathrm{~s}$. It should be stressed that multiple absorption peaks were not observed. 


\section{Analytical figures of merit}

A comparison of the detection limits of the present procedure are summarized in Table 3 for conventional FAAS, HG-ET-AAS and with four atom trap designs. While direct comparison of detection limits is often misleading (owing to the use of different systems, operating conditions and modes), it is clear that the detection limits, achieved with in situ atom trapping FAAS are two to three orders of magnitude superior to those obtained with direct conventional flame AAS.

The analytical performance characteristics were evaluated for indium and thallium. The limits of detection (LOD) calculated according to the IUPAC recommendation (based on a $3 \sigma_{\text {blank }}$ criterion) were obtained by the use of optimized operating conditions. Since no detection limits, obtained by similar techniques, are available, the results are compared with the HG-ET-AAS (in situ trapping) technique (Table 3 ). It can be seen in Table 3 that the detection limits for the developed procedure are evidently better when compared with other atom traps. Detection limits obtained with a $120 \mathrm{~s}$ long collection time were in the ppt $\left(\mathrm{pg} \mathrm{mL}^{-1}\right)$ range and are the best ones. These limits are low enough to suggest that this procedure provides a feasible alternative to the use of HG-ET-AAS (in situ trapping) method for the determination of these hydrides forming trace elements. The achieved limits of detection (LOD): 0.60 and $0.40 \mathrm{ng} \mathrm{mL}^{-1}$ for In and $\mathrm{Tl}$, respectively, are at least ten times better than the LOD achieved for In and $\mathrm{Tl}$ in situ trapping in commercial graphite furnace with subsequent detection limits: 6.3 and $4.6 \mathrm{ng} \mathrm{mL}^{-1}$, respectively (reported by Liao and $\mathrm{Li}^{10}$ and by Liao et al. ${ }^{12}$ ). The average blank levels of
In and $\mathrm{Tl}$ for the total analytical procedures are 1.4 and $1.1 \mathrm{ng}$, respectively. There was no attempt made to reduce contamination and, subsequently, to achieve even lower LOD. Six replicate measurements of the total procedure (reagent) blank solution were carried out and the relative standard deviation (RSD) of the background values was calculated. Precision was in the range of $4.4 \%$ (In) and $5.2 \%(\mathrm{Tl})$ (evaluated as peak area). This reflects the cumulative imprecision of all of the sample handling, hydride generation, trapping, atomization and detection steps.

\section{Accuracy of the method}

To establish the accuracy of the approach, several solutions of one certified reference material were analyzed. Table 4 demonstrates the accuracy of the proposed method that was based on the agreement of the results with the certified value $(\mathrm{Tl}$, mean $\pm 95 \%$ confidence interval includes the certificate value) or information value (In). All experimental concentrations agreed fairly well with the certified or information values. Although no interference study was undertaken, it is obvious, from the data, that there are no systematic errors due to the presence of the matrices. Aqueous standard calibration was used to obtain accurate results.

\section{Conclusions}

It was demonstrated that the present hyphenated technique, using a continuous mode hydride generation gas phase in situ trapping on an integrated silica tubes trap, followed by atomization in acetylene-air flame with

Table 3. Comparison of limit of detection $(\mathrm{LOD})^{\mathrm{a}}$ for indium and thallium obtained using various atom traps $\left(\mathrm{ng} \mathrm{mL}^{-1}\right)$

\begin{tabular}{|c|c|c|c|c|c|c|c|c|c|c|c|c|}
\hline \multirow[t]{2}{*}{ Element } & \multicolumn{2}{|c|}{ Flame AAS } & \multicolumn{2}{|c|}{ STAT } & \multicolumn{2}{|c|}{$\mathrm{WCAT}^{\mathrm{b}}$} & \multicolumn{2}{|c|}{$\mathrm{IAT}^{\mathrm{c}}$} & \multicolumn{2}{|c|}{ HG-IAT $^{\mathrm{d}}$} & \multicolumn{2}{|c|}{$\begin{array}{c}\text { in situ trapping } \\
\text { HG-ETAAS }\end{array}$} \\
\hline & DL & $\mathrm{X}^{\mathrm{e}}$ & DL & $\mathrm{X}^{\mathrm{e}}$ & DL & $\mathrm{X}^{\mathrm{e}}$ & $\mathrm{DL}$ & $\mathrm{X}^{\mathrm{e}}$ & DL & $\mathrm{X}^{\mathrm{e}}$ & $\mathrm{DL}$ & $\mathrm{X}^{\mathrm{e}}$ \\
\hline In & 250.00 & 1.0 & 110.00 & 2.3 & 30.00 & 8.3 & 10.00 & 25.0 & 0.60 & 416.7 & $6.3^{\mathrm{f}}$ & 39.7 \\
\hline $\mathrm{Tl}$ & 180.00 & 1.0 & 70.00 & 2.6 & 25.00 & 7.2 & 8.00 & 22.5 & 0.40 & 450.0 & $4.6^{\mathrm{g}}$ & 39.1 \\
\hline
\end{tabular}

adetection limit defined by 3 blank criterion $(n=6) ;{ }^{b} 2$ min collection time; ${ }^{c} 2$ min collection time; 2 min collection time; ${ }^{\mathrm{e} e n h a n c e m e n t}$ (improvement) factor; ${ }^{\mathrm{r}}$ ref. ${ }^{10}$ for sample volume of $100 \mu \mathrm{L}$; ${ }^{\mathrm{g}}$ ref. ${ }^{12}$ for sample volume of $200 \mu \mathrm{L}$.

Table 4. Analytical results of indium and thallium from certified reference material. All values in $\mathrm{mg} \mathrm{kg}^{-1}$

\begin{tabular}{|c|c|c|c|c|c|c|}
\hline \multirow[t]{2}{*}{ Sample } & \multicolumn{3}{|l|}{ In } & \multicolumn{3}{|l|}{$\mathrm{Tl}$} \\
\hline & Found & Certified $^{\mathrm{a}}$ & Recovery & Found & Certified $^{\mathrm{a}}$ & Recovery \\
\hline GBW 07302 & $0.051 \pm 0.004^{\mathrm{b}}$ & $0.046^{\mathrm{c}}$ & $110.9 \%$ & $1.7 \pm 0.1^{\mathrm{b}}$ & $1.9 \pm 0.5$ & $89.5 \%$ \\
\hline Stream & & & & & & \\
\hline Sediment & & & & & & \\
\hline
\end{tabular}

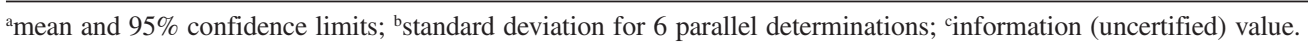


simultaneous direct thermal heating of the collector (atomizer), can be used for the determination of ultra-trace amounts of indium and thallium in analytical samples. Following the trapping stage, the performance of the device and related problems are quite similar to the case of hydride generation-electrothermal atomization (atomizer) HG-ETAAS. The detection limits of this HG-IAT-FAAS system for In and $\mathrm{Tl}$ were dramatically improved when compared with those reported for measurements of In and Tl by any flame AAS approach. This very simple technique constitutes an attractive alternative to HG-in situ trapping-ET-AAS system at significantly lower cost. The achieved, extremely low detection limits for In and Tl, 0.60 and $0.40 \mathrm{ng} \mathrm{mL}^{-1}$, is strikingly better ( $\mathrm{ca}$. one order of magnitude) than those for the in situ trapping of hydrides in a commercial graphite furnace: $6.3 \mathrm{ng} \mathrm{mL}^{-1}$ (Reference 10) and $4.6 \mathrm{ng} \mathrm{mL}^{-1}$ (Reference 12), respectively.

This proposed novel experimental approach, offers an interesting perspective for the determination of other hydride forming elements, e.g., $\mathrm{Ge}$ and $\mathrm{Te}$ (this is the subject of on-going research) and, possibly $\mathrm{Bi}, \mathrm{Sb}$ and $\mathrm{Sn}$, based on the use of atom trapping technique. Additionally, it is attractive, operating in the range of $\mathrm{pg}$ $\mathrm{mL}^{-1}$, method for laboratories not equipped with any graphite furnace apparatus.

\section{Acknowledgments}

Financial support by the State Committee for Scientific Research (KBN), Poland, Grant No. 3 T09A 14027 is gratefully acknowledged.

\section{References}

1. Welz, B.; Sperling, M.; Atomic Absorption Spectrometry, WileyVCH: Weinheim, 1999.

2. Dedina, J.; Tsalev, D. L.; Hydride Generation Atomic Absorption Sspectrometry, John Wiley \& Sons: Chichester, 1995.

3. Tsalev, D. L.; Atomic Absorption Spectrometry in Occupational and Environmental Health Practice, CRC Press: Boca Raton, 1995.
4. Peter, A. L. J.; Viraraghavan, T.; Environ. Int. 2005, 31, 493.

5. Matusiewicz, H.; Sturgeon, R. E.; Spectrochim. Acta, Part B 1996, 51,377

6. Matusiewicz, H.; Spectrochim. Acta, Part B 1997, 52, 1711.

7. Busheina, I. S.; Headridge, J. B.; Talanta 1982, 29, 519.

8. Yan, D.; Yan, Z.; Cheng, G-S. Li, A-M.; Talanta 1984, 31, 133.

9. Castillo, J. R.; Mir, J. M.; Gomez, M. T.; Microchem. J. 1988, $38,387$.

10. Liao, Y.; Li, A.; J. Anal. At. Spectrom. 1993, 8, 633.

11. Ebdon, L.; Goodall, Ph.; Hill, S.; Stockwell, P.; Thompson, K. C.; J. Anal. At. Spectrom. 1995, 10, 317.

12. Liao, Y-P.; Chen, G.; Yan, D.; Li, A-M.; Ni, Z-M.; Anal. Chim. Acta 1998, 360, 209.

13. Zhu, D.; Xu, S.; At. Spectrosc. 2000, 21, 136.

14. Matusiewicz, H.; Kopras, M.; J. Anal. At. Spectrom. 1997, 12, 1287.

15. Matusiewicz, H.; Krawczyk, M.; Anal. Sci. 2006, 22, 249.

16. Matusiewicz, H.; Krawczyk, M.; Microchem. J. 2006, 83, 17.

17. Korkmaz, D.; Kumser, S.; Ertaş, N.; Mahmut, M.; Ataman, O.Y.; J. Anal. At. Spectrom. 2002, 17, 1610.

18. Ertaş, N.; Korkmaz, D. K.; Kumser, S.; Ataman, O. Y.; J. Anal. At. Spectrom. 2002, 17, 1415.

19. Guo, X-m.; Guo, X-w.; J. Anal. At. Spectrom. 2001, 16, 1414.

20. Korkmaz, D. K.; Ertaş, N.; Ataman, O.Y.; Spectrochim. Acta, Part B 2002, 57, 571.

21. Korkmaz, D.; Dedina, J.; Ataman, O.Y.; J. Anal. At. Spectrom. 2004, 18, 255.

22. Kratzer, J.; Dedina, J.; Spectrochim. Acta, Part B 2005, 60, 859.

23. Kratzer, J.; Dedina, J.; J. Anal. At. Spectrom. 2006, 21, 208.

24. Matusiewicz, H.; J. Anal. At. Spectrom. 1989, 4, 265.

25. Matusiewicz, H.; Kopras, M.; Sturgeon, R. E.; Analyst 1997, $122,331$.

26. Matusiewicz, H.; Sturgeon, R. E.; Luong, V.; Moffatt, K.; Fresenius' J. Anal. Chem. 1991, 340, 35 (and references cited therein).

27. Matusiewicz, H.; Anal. Chem. 1994, 66, 751.

Received: July 20, 2006

Web Release Date: February 22, 2007 